\title{
1. Viewing Korean employment and industrial relations
}

\author{
Young-Myon Lee and Bruce E. Kaufman
}

\section{THE FIELD OF EMPLOYMENT-INDUSTRIAL RELATIONS: HISTORICAL DEVELOPMENT AND CURRENT STATUS}

This introductory chapter provides the foundation of understanding for the volume and subsequent chapters. In it we frame the big picture, define key terms, and give helpful historical perspective to the field of EIR. The discussion starts at the general level regarding meanings, principles, and features of employment-industrial relations and then moves to the specific case of EIR in Korea.

The field of study and practice covered in this volume was for most of the twentieth century known in English-speaking countries as industrial relations (IR). The IR term first came into popular usage in the 1910s in the USA and Canada, slowly spread to Britain, Australia, and other empire countries in the 1920s-30s, and then in the 20 years after World War II gradually spread to continental Europe, Asia, Latin America, and other world regions. Particularly important in promoting the field of industrial relations outside its original Anglophone base was the International Labour Organization (ILO), founded in 1919, and the International Industrial Relations Association (IIRA, now ILERA - the International Labour and Employment Relations Association), founded in 1966.

Even for English-speaking people, the term industrial relations is opaque in its exact meaning and this has had the unfortunate effect of leading to different understandings both within and across nations of IR's conceptualization and central subject area. As conceived by pioneer writers on industrial relations in the 1910s, such as American John Commons and Canadian William Lyon Mackenzie King, the new field of IR was centered on a particularly important but problem-prone institution in modern capitalism - the employment relationship. Commons, King, and others of that era spoke of the industrial relation as a close synonym for the employment relation and, for this reason, some American writers in the 1910s-20s 
called the subject by the more transparent name - employment relations (ER).

In this early conceptualization, IR and ER - or what today is increasingly called employment-industrial relations (EIR) - were conceived as a broad cross-disciplinary social science field that covers all forms and types of employment relationships spanning private and public, union and non-union, and formal and informal sectors. The purpose of EIR, in this early view, is to understand the origin, structure, regulation, and operation of employment relationships, the behaviors and outcomes that grow out of them, and new or improved methods of organizational design and management, collective worker organization and bargaining, labor employment laws, social welfare programs, macroeconomic stabilization, and codes of ethical behavior that can increase the economic performance and social welfare of the employment relation for all stakeholders.

As King depicts in a remarkable set of nine diagrams in the back of his book Industry and Humanity (1918) - arguably the first book in the world specifically written on the concept and theory of IR - a nation's employment-industrial relations system (EIRS) resembles a hierarchical pyramid (illustrated in Figure 1.1). At the bottom level are the millions of people in the nation's workforce who as employer, manager, staff, or employee go to work each day and together produce the nation's gross domestic product (GDP). The institution that brings them together, and forms the heart of EIRS, is the employment relationship as created by the legal contract of employment. The contract of employment is between two people and may be a formal written agreement both people sign or an informal agreement worked out through face-to-face discussion and accepted by a mutual bow or shaking of hands. Every person in an employment relationship has certain common human and material interests (objectives) they seek to satisfy, such as respect, fair treatment, good pay, safe job conditions, and interesting work. They also have separate interests defined by position and function in society and the workplace (Heery, 2016). Coordinating, aligning, and balancing all these diverse human relations and interests, resolving inevitable conflicts and problems created by these different relations and interests, maintaining order, peace, and harmony in the workplace, and accomplishing all these challenging tasks in a way that yields the highest material wealth and human welfare are, in King's view, the heart of the employment-industrial relations field.

Pre- and post-contract institutions are critical to every EIRS. Before a contract of employment is created comes the labor market where companies with job openings and workers wanting jobs go in search of the best match. The labor market is an exchange institution governed by competition and demand/supply and sets upper and lower boundaries on the terms 
of an individual labor contract (wages, work hours, benefits, etc.). After a contract of employment is created comes the firm (organization) where the new employee is given a job, perhaps as a manager, scientist, teacher, chef, or truck driver, and told by a superior what to do. The organization is a production institution governed at the top by an owner or chief executive officer (CEO) who, with executives and middle and front-line managers, directs non-supervisory production employees in the day-to-day tasks of producing the goods and delivering the services to customers. The conflicting logics of individual competition and exchange in labor markets, team cooperation and production in organizations, and divergent human psycho-social needs and emotions generated in superior-subordinate group interactions, are therefore a central problem and source of inefficiency and conflict in all employment relations and are never capable of full resolution (outside of imaginary worlds, such as the economist's model of perfect competition). Above the labor market and employing organization in the EIRS is an ascending hierarchy of other institutions, such as employers' associations, independent labor unions, and non-government organizations (NGOs), with, at the very top, the government of the nationstate that sets and enforces resource endowments and the rules of the game.

The practical and intellectual impetus for creating the new field of employment-industrial relations at the beginning of the twentieth century was the growing threat posed to governments and social order by what became popularly known as the 'Labor Problem' (Arbeiterfrage in German), 'Social Question' (question sociale in French), or 'Social Problem' (shakai mondai in Japanese) (Kaufman, 2004a). These terms connoted the growing nationwide polarization in relations between the capital and labor classes, spread of violent strikes and protests bordering on civil insurrections, and growth of militant left-wing unions and political groups demanding the replacement of capitalism with socialism. If better industrial relations were not worked out, many people in the middle and upper classes of these nations feared the degenerating labor problem could lead to the class war and overthrow of capitalism and democracy predicted by Marx, Engels, and numerous other socialist-anarchist revolutionaries. As an illustration of the mainline spirit and purpose of industrial relations, after careful and sympathetic study of Marxism and the socialist critique of capitalism, American IR founder John Commons concluded that reforming and humanizing democratic capitalism is the better strategy for all classes, including the exploited and oppressed workers at the bottom of the system, than is the alternative of Marxist revolutionary socialism and dictatorship of the proletariat. He observes, therefore, that he devoted his academic career to advancing the science and practice of industrial relations to 'save capitalism by making it good' (Commons, 1934a, p. 143). 
This broad conception of EIR includes the field of personnel/human resource management (HRM), accepts capitalist employers and management as important and legitimate parts of an EIR system, and while giving plenty of criticism to greedy, exploitative employers also does not hesitate to criticize corrupt, monopolistic labor unions and autocratic, coercive governments. Nonetheless, nearly everyone involved in creating the new field of industrial relations, both in North America and Europe, concluded that a major reason their nation's EIR systems were increasingly producing social bitterness and workplace conflict was that the upper class of rich industrialists, large land owners, and wealthy social elites effectively controlled the governments and used the power of the governments to create a 'rigged system' of unbalanced/unfair rules that favored their interests. Over the nineteenth century, workers in these Western countries were treated as a socially inferior class, excluded from effective voice in government, forced to survive on daily wages often at the subsistence level with no job security or social safety net programs, and made to work under authoritarian bosses with deplorable work conditions, discriminatory and unfair treatment, and the constant threat of being terminated for any reason. To head off worsening class conflict and violent labor strikes, the early IR pioneers - including not only Commons in the USA but Sidney and Beatrice Webb in Britain, Lugo Brentano in Germany, and Noburu Kanai in Japan - placed particular emphasis on strengthening and spreading independent labor unions and collective bargaining. Unions and collective bargaining were seen as a valuable means of providing workers with more voice and representation in the national government (perhaps through a labor party, as in Britain), more countervailing power in labor markets and wage determination by replacing individual company-worker bargaining with collective company-union bargaining, and forcing employers to change internal management and workforce governance from industrial autocracy to industrial democracy.

The development and institutionalization of industrial relations as an area of academic study and practice first occurred in the USA, partly through the work and financial support of progressive businesspeople like John D. Rockefeller, Jr. (Kaufman, 2004b). The participation of businesspeople, and America's unique individualist and capitalist culture, made it possible for the American founders of IR to promote greater unionism and collective bargaining while at the same time giving a place in the field to progressive non-union employers and the practice of unitarist (unity of interest) personnel/HRM. In other countries, however, the people who became interested in industrial relations typically had stronger pro-union and anti-capitalist/management sentiments, in part reflecting the stronger class divisions, larger inequalities of wealth, and slower extension of suf- 
frage rights in these countries. The best early example is Britain and the Webbs. The Webbs, cited by many people in Britain as founders of the IR field for their landmark book Industrial Democracy (1897), were strong supporters of trade unionism, trenchant critics of capitalism and personnel/HRM, and advocates of a non-Marxist type of socialist planned economy. When the Great Depression of the 1930s wrecked the legitimacy of capitalism and the welfare capitalist class of progressive non-union companies, most IR supporters in the USA shifted position and, while still opposing socialism, became more overtly pro-collective bargaining and skeptical-to-critical of non-union employment relations.

Hence, from the 1940s onward, the field of EIR became more narrowly defined in the USA and across the rest of the world as largely centered both intellectually and ideologically on the study and promotion of independent unionism, collective bargaining, tripartite interest representation and voice, and supportive government laws and programs. To the degree that there was a split in industrial relations after World War II, it was no longer over the merits of non-union HRM vs union collective bargaining (almost everyone favored the latter) but, rather, centered on other divides. One such divide was between the majority of IR pluralists (like Commons) who favored a reformed and regulated capitalism, versus a minority of IR radicals who favored either evolutionary democratic-state socialism (like the Webbs) or revolutionary class overthrow of capitalism and a one-party communist state (like Marx). Other divides, respectively, were between a European type of centralized/corporatist collective bargaining system and an Anglo-American type of decentralized/company-level bargaining system and different disciplinary orientations, such as economics in North America and Japan, sociology and politics in Britain and Northern Europe, and labor law in Southern Europe and Latin America.

Being increasingly criticized and rejected in EIR (e.g., Flanders and Clegg, 1954; Dunlop, 1958), personnel/HRM/human relations after World War II gradually broke away and established themselves as not only a separate area in business schools focused on managing employees to increase organizational effectiveness and company profits but also as a rival individualist/non-union approach to employment relations in contradistinction to IR's collectivist/union approach. As long as the majority of wage and salary workers across nations were union members, the narrow labormanagement conception of IR worked well and gave the field a good position to remain strong and vibrant in universities and the business world. However, starting in the 1970s and then gaining speed, union density and influence began to shrink noticeably in many countries, starting first in the USA and other Anglophone/neoliberal economies and then to various degrees in many others. As unions declined, the field of industrial 
relations followed, marked by falling student enrollments, closing of IR programs and centers, and a shift of students and faculty research interest to business schools and HRM. By the late 1990s, concern deepened to the point that leaders in the field began to speak of IR as being in a state of crisis and perhaps terminal decline (e.g., Kelly, 1998; Kochan, 1998; Piore, 2011).

In Europe and other regions where union density, sectoral-level collective bargaining, and extension of union contract terms to non-union firms have held up better, the field of industrial relations is still predominantly defined in terms of the narrower union/labor-management dimension of employment relationships. The trend in Anglophone countries, on the other hand, has been to try to reposition the field so it embraces the broader employment relationship conception with which IR started in early twentieth-century North America. As part of this trend, the industrial relations term - increasingly seen as having an outdated 'smokestack and strikes' image - is gradually being phased out and replaced by terms such as employment relations, employment-industrial relations, and similar permutations. As an example, the International Industrial Relations Association recently changed its name to International Labour and Employment Relations Association. To varying degrees across countries and regions, this name change also signals greater acceptance and interest in personnel/HRM, unitarist-type non-union employment relations, and alternative forms of worker representation and voice. Nonetheless, EIR remains distinct from HRM in covering both employer and employee sides and interests, taking a more inclusive social science and cross-disciplinary perspective on employment relationships, also taking a more political economy and macro-sociology approach in order to capture the top-to-bottom structure of class and power relations in EIR systems, and welcoming a wider breadth of perspectives than typically found in business schools with unitarist pro-employer researchers at one end and radical pro-union researchers at the other.

The broad conception of the EIR field can be thought of as the political economy of the employment relationship. A representative formalization is depicted in Figure 1.1 (Kaufman, 2004a). The EIR system is represented as a pyramid of hierarchical relations, institutions, and power positions, starting at the top of the pyramid with the ultimate rule maker and enforcer the sovereign nation-state. The state, whether a military dictatorship or representative democracy, establishes through its law-making power the overall structure of the EIRS, such as the existence/non-existence of a market economy and wage-labor type of employment relation, the legal regime that specifies the respective rights, duties, and powers of employers and employees, the ability of workers to form independent trade unions, 


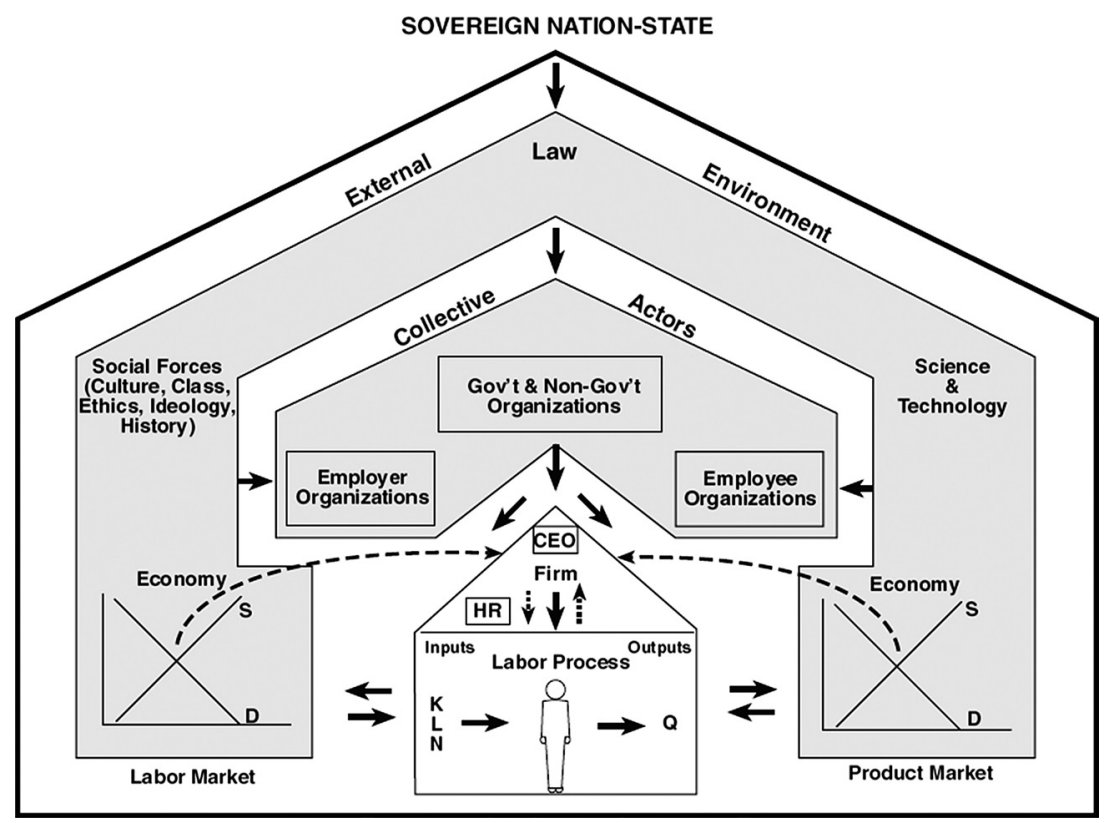

Note: $\mathrm{D}$ is demand; $\mathrm{S}$ is supply; $\mathrm{K}$ is capital; $\mathrm{L}$ is labor; $\mathrm{N}$ is natural resources; $\mathrm{Q}$ is outputs of goods and services.

Source: Kaufman (2004a, p. 50).

\section{Figure 1.1 An employment relationship model of EIR}

and the power position of employers vs employees in external labor markets and internal firm governance.

At the bottom of the EIRS in the micro-level pyramid is the individual firm/organization, with CEO at the top, ranks of managers underneath (including the HR department), and the production/labor process part of the firm in the rectangle where front-line managers assign employees (the human figure in the illustration) to jobs and direct their work. The employees are obtained from the labor market on the left side of the firm and the output they produce, with the help of capital and natural resources, is sold to customers in product markets on the right side. The competing logics of market exchange, team production, and labor as a commodity vs human essence are illustrated.

Above the firm and micro-level markets are three different collective actors (in the boxes) - employer organizations, employee organizations (e.g., labor unions), and government and non-government 
organizations - which to varying degrees structure and regulate the employment relation below them. (One or more elements in each box, such as employers' association, labor union, or human rights watchdog group, may not exist in some situations.) Yet, higher in the pyramid are additional external forces (besides the markets) that shape the structure and outcomes of every EIRS, including social/cultural/ethical, law, and science and technology. The outcomes of the system, such as wages, hours, productivity, worker treatment, union density, and amount and intensity of strike activity, are determined in a circular process of exchange, command, formal/ informal negotiation, social norms, and custom. The model applies to all employment relationships, although with modifications and contingencies to fit each particular situation.

\section{EMPLOYMENT AND INDUSTRIAL RELATIONS IN KOREA}

The employment-industrial relations subject examined in this volume for Korea is unique in many interesting ways, yet, at the same time, has also to be seen against this larger backdrop of world-level intellectual trends and socio-political developments. Thus, at one level, it is possible to say that industrial relations came to Korea in the late nineteenth century, as was the case with the USA, Germany, and Japan. The first labor strikes by wage earners occurred in the late 1880s and the first independent union was formed in 1898 among longshoremen (dock workers) (Lee, 1993). However, this nascent beginning was then interrupted and forestalled for nearly a century by a series of events: the Japanese colonization and imperial rule of Korea from 1910 to 1945, the devastation of the Korean Civil War from 1950 to 1953, and the autocratic rule of Presidents Park and Chun from 1960 to 1988. Furthermore, after World War II, the labor unions that did emerge and start to organize and collectively represent workers were sharply divided between reformist-capitalist and radicalcommunist wings, which led to considerable violent infighting and disruptive strikes and, in the early 1950s, growing suppression of radical unions and leftist activists by the US-backed regime of President Syngman Rhee (1948-60).

The scholarly side of industrial relations started to appear in the 1950s70 s in selective writings of a few academics, often educated in the West. Important names include Jong-tae Choi, Yoon-whan Kim, Nak-jung Kim, Chang-wha Cho, Young-ki Park, and Chi-seon Kim (Lee and Lee, 2005). Among these people, Jong-tae Choi deserves to be highlighted.

Choi studied European industrial relations in Austria in the late 1960s 
and authored the Korean-language book, Modern Industrial Relations in 1981. Choi divides industrial relations into two frameworks: one considering the micro-perspective of companies, and the other from a macroperspective of society and the nation, with his focus being the former. $\mathrm{He}$ further differentiates industrial relations from personnel management, as industrial relations assumes a relationship between organizations, whereas personnel management assumes a relationship between individuals. $\mathrm{He}$ emphasizes the need to take into account political forces in addition to economic, social, and technological aspects when examining company industrial relations, highlighting dimensions of power, collective structure, socio-economic structure, communication channels, and conflict resolution processes as factors that make up the political system in a company (Choi, 1981, p. 51).

Choi identifies trade unions and employers' associations as the key institutions to all industrial relations, and collective bargaining and worker participation as its critical instruments. Issues in industrial relations are not just limited to matters of power and authority and economic and material wealth, but also relate to social and spiritual wellbeing. He posits that as industrial relations develop, the issues they are concerned with evolve: power-authority issues such as union recognition feature at an initial stage; economic and material issues such as wages and working hours come to the fore at the early development stage; seniority and job security are a focus during growth; and, finally, social and spiritual issues such as organizational goals and job satisfaction take center stage during the mature stage of industrial relations development (Choi, 1981, p. 368).

After these formative writings, the real emergence of the EIR field in Korea occurred in 1987 and lasted until 1989. The late 1980s marked the high-water mark for trade union power and popular approval because the unions and their brave leaders and activist members were not only instrumental in bringing down the Chun military dictatorship and restoring democracy and self-rule to the people of Korea but had similarly resisted all types of foreign domination and influence, starting in the 1910s with Japanese colonialist rule and continuing after World War II with the American-dominated Rhee and Park regimes. Unfortunately for the unions, the social-political environment from the 1990s onward turned more conservative and less favorable to their cause.

The downward trend in union density and popular approval has negatively affected the Korean EIR field, just as in many other nations. It was the narrow union/labor-management version of industrial relations that was planted in the 1960s and then rapidly blossomed in the late 1980s to early 1990s. The Korean term for industrial relations, for example, is " nosa 
kwankye', which, literally translated, means labor-management relations. The field of IR received a big boost with the creation of the Korea Labor Institute (KLI) in 1988, as the KLI has over the years sponsored many research projects, workplace surveys, and reports on industrial relations topics. Also, in 1988, Soongsil University established the first standalone IR graduate program in Korea, the Graduate School of Labor and Management Relations, and in 1994 a Graduate School of Labor Studies was created at Korea University in Seoul. Numerous other universities also established IR programs, centers, and undergraduate or graduate majors and areas of concentration. Also of importance for the development of EIR in Korea, the Korean Industrial Relations Association (KIRA) was founded in 1990, the same year the Journal of Industrial Relations began publication from Seoul National University, and in 1991 the KIRA sponsored a second IR journal, the Korean Journal of Industrial Relations. Also encouraging growth of the field, many dozens of young Koreans traveled abroad, particularly to the USA, to obtain EIR graduate degrees.

The fact that the dominant conception of industrial relations in Korea for many years has been the narrower union/labor-management version has become an increasingly serious problem for the continued vitality of the field as the unionized sector of the workforce falls to 10 per cent. Like in other countries, the people active in EIR in Korea have responded with a number of initiatives. One is to broaden the teaching and research focus to include non-traditional forms of representation and voice, problems and needs of employees in non-union companies, the role of worker representation and voice in high-involvement work systems, and the special problems of informal sector and temporary contract workers and women and immigrants. A second initiative is to go a step further in the broadening effort and, like in other countries, explicitly refocus the field from narrow, labor union-focused IR to the broader employment relations interpretation of EIR. Part of this shift means that personnel/HRM becomes, once again, a complementary part of the EIR field and not a rival substitute or enemy. Moving to this broader ER conception is facilitated in the Korean case because several of the early IR graduate programs adopted a broadbased cross-disciplinary faculty and curriculum structure with diverse areas such as labor economics, human resource management, labor law, and social policy. Nonetheless, the practical reality is that competition and rivalry between business school HRM and social science EIR remain strong and students frequently see the former as the better specialization for getting jobs. 


\section{THE NATIONAL HISTORY THAT SHAPED THE KOREAN EIR SYSTEM}

The Joseon dynasty (1392-1910) ushered in what can be considered the modern, united and independent Korea, although Korea formally became a united country under the earlier Goryeo Dynasty (918-1392 AD). The Goryeo dynasty transformed Korea to a centrally controlled bureaucracy with a state religion (Buddhism) and means of collecting state revenues, thus making it possible to invest in significant works of national culture and art. But the Goryeo system never completely settled the matter of state versus military control of the body politic, and tensions between civilian nobles and military leaders continued. Both groups cultivated influence with successive Goryeo kings and endeavored to manipulate edicts arising from the powerful ministerial assemblies, leading to fractured and inconsistent leadership.

The Joseon dynasty took a different approach under the leadership of scholar-ruler Do-jeon Jeong. Confucian principles guided Jeong's every decree, which covered the establishment of Joseon tax laws, the education system, state and municipal governance structure, and legal foundations. Private armies were abolished, and a national fighting force established. Courts opened to hear the grievances of the people, censuses were taken, administrators dispatched to principalities, and later a national script was created to encourage literacy. Joseon was a centralized administrative state.

Confucian-designed hierarchy ruled government administration and the conduct of business: older people are respected by younger; classical education is valued above any profession; scholars are treated better than merchants, who are treated better than farmers, and so on. This Confucian-oriented tradition led to the seniority-based wage system, still prevalent in Korean companies, and also plays a large role in promotion decisions since the culture makes it very difficult for a person of a younger age to be a boss of an older person. White collar workers are accustomed to being paid more than other employees regardless of their performance because of their occupational position and educational background. The other key aspect of this tradition is collectivism - the prioritization of group harmony above self-interest. The rules governing right relationships prescribed in Confucianism are meant to achieve a state of harmonious collectivism in society. These cultural principles work together to create a social and workplace system featuring a relatively sharp and persistent division of classes in Korean society and built-in tendency to resist challenge or change for the sake of social harmony.

Another aspect of Korean culture important to understanding the nation's unique EIR experience is captured by the word 'haan'. Haan is the 
Korean people's sense of profound and inexpressible 'bottled up' anger and resentment created by a deep, unforgettable experience of injustice that has no means of redress and removal. Some people point to the Confucian traditions underpinning a very unequal society as the source of haan, but perhaps more broadly it stems from Korea's history of invasion, subjugation and exploitation by foreign powers. During the Joseon dynasty, Japan invaded and plundered the country repeatedly. China also invaded and controlled Korea for many decades in the seventeenth century, demanding compliance in accord with the Imperial Chinese tribute system. Despite an official policy of 'friendly neighbor' relations with Japan and China, the repeated betrayal by its Asian allies caused the Joseon dynasty to eventually close its doors.

In the nineteenth century, all of East Asia experienced the challenge of European and American imperial-commercial expansionism, but the Joseon leaders and government assembly could not agree how best to respond. However, in the latter part of the nineteenth century a decision was made to adopt an increasingly strict policy of isolationism, with the exception of continued diplomacy with China and Japan. Korean leaders maintained the fiction of the subordinate relationship with the Qing government of China out of both tradition and the need for protection. This is in contrast to Japan's own adaptation of Western political, military, economic, and social forms under the Meiji Restoration, a policy meant to strengthen Japan's power and influence in East Asia and world affairs.

Japan's immediate target for greater influence and control was the Korean Peninsula. In Korea, the area of Ganghwa Island on the west coast had already been established as the staging ground for gunboat diplomacy by the 1860s. Its strategic location at the mouth of the Han River, a river that runs across the peninsula and directly to Seoul, meant that first French and then American forces used it to launch attacks of conquest and retribution. Japan then followed and used the island as a launching ground to invade Korea on the pretext of defending Japanese interests and people. To halt further military action, Korea's leaders signed the JapanKorea Treaty in 1876. Similar to other imperialist, unequal treaties before it, the agreement effectively gave Japan unrestricted trade and substantial port access on the peninsula, and also made maritime support for Japanese merchants and ships obligatory. These terms forced open the economy to outside influence while depriving Korea of development capital and business opportunities for decades to come. Importantly, the treaty also gave the Japanese extraterritoriality rights, which paved the way in later years for more conflict and annexation.

With the end of the conflict, Japan used its power to introduce modern production and management techniques in agriculture, mining, com- 
merce, manufacturing and distribution. Other Western countries, and also Russia, which had imperialist ambitions in Asia, also competed for influence and helped introduce modern industry and commerce to Korea. However, because Japan wanted to expand its control of the region, it began by challenging China's weakening suzerainty over the Korean Peninsula. After two years of warfare (1894-95) Japan forced China to cede control. A decade later, a similar war for control of Korea broke out between Japan and Russia and, again, the Japanese won a decisive victory. Russia's defeat was the first experienced by a European power at the hands of an Asian country. Japan used Korea as a wartime supply source for materials and men and women, which was then repeated in later wars. Japanese public anger at what was perceived as inequitable peace terms ending the war, negotiated in 1905 with the help of American President Roosevelt, set the stage for later conflict and an end of Korea's short national independence.

Japan formally annexed Korea in 1910. The Japanese military initially exercised colonial rule, but after protests and riots in 1919, military rule became more moderate with greater civilian involvement. Japan introduced considerable industrialization to Korea and encouraged urbanization to fill factory positions, which helped push forward the modernizing influences already underway. The Korean people's sense of haan, however, was further inflamed because they saw these actions, perhaps of some benefit in their own right, as part of Japan's self-interested strategy to exploit Korea in order to advance its military power and domestic economy. Koreans recruited to factory villages experienced low wages and inhumane working conditions. Scholars often trace the Korean labor movement's militancy to the oppression and exploitation workers suffered in Japanese factories.

After Japan's World War II defeat in August 1945, a US-led military administration governed South Korea below the 38th parallel, while a USSR-led military administration governed North Korea above the 38th parallel. Labor leaders who had managed to nurture their progressive, underground movement during the Japanese colonial period now triumphantly formalized their labor organizations. The triumph was short-lived. The US-led administration became wary of the labor unionists' leftist ideology and connection with the communist 'Nam-ro' or Korean Workers' Party, whose leaders had relocated to Pyeongyang in North Korea. As a counterbalance against the increasingly destabilizing influence of the militant and numerous Nam-ro supporters, the USA behind the scenes helped President-to-be Syngman Rhee organize rival labor organizations with a more conservative ideology while jailing or killing radical union leaders and activists. 
The governments of both the North and South parts of Korea claimed rightful control of the peninsula, despite the division imposed by First World powers. After months of growing hostility, Soviet and Chinabacked Northern forces invaded the South in 1950, starting the Korean War. The United Nations (UN) came to the aid of the South, led primarily by US forces. The forces of China, Russia, and the US engaged in a bitter proxy war that devastated the country. The warfare between the two sides resulted in horrendous destruction and violence, with the civilian population caught in the middle and frequently subject to indiscriminate bombings, massacres, and rape and plundering. By the time of the armistice agreement in 1953, a large part of the skilled workforce was killed or injured and most of the industrial infrastructure was obliterated, plunging the country into an economic and humanitarian crisis. (The armistice agreement ended the fighting but, technically, the North and South are still at war.)

The subsequent repressive and corrupt rule under US-backed Syngman Rhee, along with the continued presence of tens of thousands of US soldiers, led to growing anti-US sentiment in Korea. As can be appreciated, the many years of imperialist jockeying for control of Korea, massive wartime death and destruction at the hands of foreign militaries, the imposed division of the Korean Peninsula into separate parts, and quasi-permanent US military presence all heightened the Korean people's collective feeling of haan and the labor movement's orientation toward oppositional confrontation and militancy.

During the Korean War, three major labor laws were enacted in the South: the Labor Standards Act, the Labor Union Act, and the Labor Relations Commission Act. Although the details of these laws are discussed more fully in subsequent chapters, the fact that these laws were enacted - but then not actively administered and enforced for many years - is another characteristic feature and source of conflict in Korean employment-industrial relations.

\section{THE KOREAN EIR SYSTEM: INSTITUTIONS, COLLECTIVE ACTORS, AND SOCIO-CULTURAL TRADITIONS}

Every employment relations system is embedded within and regulated by a superstructure of institutions, collective actors, and social-cultural traditions. 


\section{Institutions}

An institution is a human-made collective entity that 'expands, liberates, and controls' the behavior of individuals (Commons, 1934b). Under this definition, Korea has more than 4 million business institutions, including self-employed and independent contract workers. Most of these institutions are involved in an employment relations system in that they hire employees. The Korean population is roughly stable at around 51 million, with approximately 26.25 million people employed. To give further context, roughly 2.5 million work in companies with 300 or more employees. Samsung Electronics, Hyundai Motor Company, Kia Motors, KT, KEPCO, Hyundai Heavy Industries, Lotte Shopping, POSCO, Korean Air, and LG Electronics each employ more than 10000 workers, but the vast majority of Korean workers are employed in small to medium-sized enterprises (SMEs). Approximately 21 per cent of those employed work in the public sector.

\section{Collective Actors}

In addition to firms and markets, consideration must also be given to the other collective actors in the Korean employment relations system - that is, employer organizations, employee organizations, and various governmental and non-governmental organizations. In Korea, representative employer organizations include the Korea Employers Federation (KEF), Korean Chamber of Commerce, Korea Federation of Small and Medium Business, and the Federation of Korean Industries (FKI). Among these, the KEF specializes in representing the employers' position regarding issues on employment and industrial relations. The KEF was established in the early 1950s and currently has more than 5000 employer members in 14 regional offices around the country.

Central to the employment relations system is workers' participation in collective organizations. Representative collective organizations include labor unions, professional employee associations (comprising lobbying, advocacy, and civil right groups), and welfare, beneficial, and churchbased associations. In Korea, the earliest labor unions were founded in seaports and mines where low-skilled laborers made a meager living. Labor organizations began to form in the 1920s when Japanese colonial policy changed from oppression to appeasement after the March 1st Movement demonstrations of 1919. These labor organizations became the cornerstone of the National Council of Chosun Trade Unions in 1945, although the US military administration dissolved this union. In 1946, Presidentto-be Syngman Rhee established the Federation of Korean Trade Unions 
(FKTU) with support from the US military administration. Successive military coups reformed the FKTU as a centralized means to control democratization and labor movements, which were restricted under the 'Grow First, Distribute Later' policy of Chung-hee Park and later Doohwan Chun, until the Great Labor Offensive period of 1987-89. Prior to the explosion of union formation and democratization of the Great Labor Offensive, union membership totaled 1 million with many independent unions. The Great Labor Offensive period gave rise to progressive labor groups opposed to the FKTU, and they formed the Korea Confederation of Trade Unions (KCTU). In 2015, these two national umbrella labor unions represented two-thirds of the 1.8 million union members. The remaining unionists joined independent unions. Until recently, public officials were barred from union membership. Only since 2006 have they been permitted to organize, and today the majority of public sector employees have joined labor unions.

Other organizations include governmental and non-governmental organizations. Examples of the former include government regulatory agencies (National Labor Relations Commission in Korea), courts, and supranational organizations such as the World Bank and the International Labour Organization (ILO). Examples of the latter include civil rights organizations, community and religious groups, and political parties.

\section{Social-cultural Forces}

An important influence on industrial relations comes from social forces of culture, class, ethics, ideology, and history. Culture is a social influence on behavior, operating through social norms, shared ideals, and widely accepted customs and conventions. We already mentioned the pervasive influence of Confucianism on Korean culture, although it is worth mentioning that the spread of Christianity in Korea has transferred some of the status from scholars to religious institutions and their leaders. The Confucian order requires workers to obey employers even when they act unfairly or unethically. At the same time, management style emphasized the paternal relationship between employer and worker, a theme familiar to the feudal class noblesse oblige encouraged in Joseon times. Challenges to traditional Confucian ethics came from Christian theology, industrialization, the social upheaval of civil war, and more recently the Western individualist mythos at the core of twentieth-century capitalism. At the same time, widespread access to education was opened up after the defeat of the Japanese, and this would have far-reaching implications for the labor movement in later decades.

Under Japanese imperial occupation in the 1920s, Korea's labor unions 
adhered closely to a quasi-socialist ideology. After World War II, spontaneous civilian organizations, the local people's committees for Korean independence, which were neither particularly socialist nor partisan, pressed for representation and a unified Korea. They were ignored and their organizations as well as Korea's nascent labor movements were branded as a socialist-political movement. Syngman Rhee was elected president and launched a brutal policy of labor oppression in the name of anti-communism and national security. Activists were jailed, tortured, and murdered. Successive authoritarian rulers followed suit until the Great Labor Offensive of 1987-89.

Science and technology also have affected employment relations through several channels. Examples include the structure of the production process, workers' physical and psychological job conditions, and scale-and-scope reasons for large-sized plants and oligopolistic market structures. Skilled workers have been replaced by mass production and automated systems. Despite an increase in the volume of production in manufacturing, the number of workers in the manufacturing sector continues to decline. While this phenomenon is not unique to Korea, the impact of firms' decisions in achieving more labor flexibility have left the precepts of the Confucian tradition in tatters.

Law is another dimension showing the influence of social forces on employment relations. We may say that the institution of law is more significant to EIR than other dimensions because it is both formal and persistent. Korea's foundational labor laws were legislated in 1950, yet they remained largely unenforced until the late 1980s. This pattern of unenforced or weak enforcement continues to this day in the body of Korean statutes, which is perhaps why the Korean citizenry have such low confidence in their judicial system. ${ }^{1}$ Korean law during the growthfirst period of the 1960s-80s was interpreted, when pushed, to prioritize employers' management rights at the expense of workers' labor and human rights, and activist leaders were often targeted, threatened, and jailed. During the three years of the Great Labor Offensive, however, the deeply unpopular government tried to maintain a neutral position with respect to industrial relations, a first in the history of the nation. Even in the more recent period of labor decline, however, union leaders are often arrested for illegal behavior when they participate in protests and strikes, while employers are rarely arrested for violation of workers' individual and collective rights.

Five forces comprise the external environment of employment relations: economic, organizational, social, technological, and legal. These forces together create a complex array of formal and informal constraints, a socalled web of rules, that guide and shape individual and collective action. 


\section{THE SOVEREIGN NATION-STATE AND KOREAN EIR}

At the apex of the employment relations system is the sovereign nationstate. Sovereignty refers to the supreme decision-making power of the nation-state and its rulers. The sovereign decides whether the economy is socialist or capitalist and whether political and economic governance structures are democratic or autocratic. Korea is defined as a democratic country as determined by its Constitution, yet was founded in authoritarian rule and, to this day, one can see an inclination to adhere to strong leaders in the corporate and public spheres.

\section{NOTE}

1. According to OECD survey data (2015), fewer than three in ten Koreans have confidence in their judicial system.

\section{REFERENCES}

Choi, J.-T. (1981), Modern Industrial Relations, Seoul: Kyoungmunsa.

Commons, J. (1934a), Myself, Madison, WI: University of Wisconsin Press.

Commons, J. (1934b), Institutional Economics: Its Place in the Political Economy, New York: Macmillan.

Dunlop, J.T. (1958), Industrial Relations Systems, New York: Holt, Rinehart \& Winston.

Flanders, A. and H. Clegg (eds) (1954), The System of Industrial Relations in Great Britain, Oxford: Basil Blackwell.

Heery, E. (2016), Framing Work, Oxford: Oxford University Press, 41-75.

Kaufman, B.E. (ed.) (2004a), 'Employment relations and the employment relations system: A guide to theorizing, in Theoretical Perspectives on Work and the Employment Relationship, Ithaca, NY: Cornell University Press 41-75.

Kaufman, B.E. (2004b), The Global Evolution of Industrial Relations: Events, Ideas, and the IIRA, Geneva: International Labour Office.

Kelly, J. (1998), Rethinking Industrial Relations: Mobilization, Collectivism and Long Waves, London: Routledge.

King, W.L.M. (1918), Industry and Humanity: A Study in the Principles Underlying Industrial Reconstruction, Boston, MA: Houghton Mifflin.

Kochan, T. (1998), 'What is distinctive about industrial relations research?', in G. Strauss and K. Whitfield (eds), Researching the World of Work: Strategies and Methods in Studying Industrial Relations, New York: Cornell University Press, pp. 31-50.

Lee, M.B. (1993), 'Korea', in M. Rothman, D.R. Briscoe and R.C. Nacamulli (eds), Industrial Relations around the World, Berlin: de Gruyter, pp. 245-69.

Lee, Y.M. and M.B. Lee (2005), 'The development of the industrial relations field 
in Korea', in D. Lewin and B.E. Kaufman (eds), Advances in Industrial \& Labor Relations Volume 14, Bingley, UK: Emerald Group Publishing Limited, pp. 279-99.

OECD (2015), 'Government at a glance 2015: Country fact sheet', accessed 12 November 2017 at www.oecd.org/gov/Korea.pdf.

Piore, M.J. (2011), 'Whither industrial relations: Does it have a future in postindustrial society?', British Journal of Industrial Relations, 49(4), 792-801.

Webb, S. and B.P. Webb (1897), Industrial Democracy, London: Longmans, Green. 